\title{
ИСТОРИЧЕСКАЯ ГЕОГРАФИЯ
}

УДК 913: 911.6; 81’373.21

DOI: $10.37490 / \mathrm{S} 221979310014961-0$

\author{
М. Г. Цинкобурова \\ Горный университет, Санкт-Петербург, Россия \\ E-mail: maschek@mail.ru
}

\section{О НЕКОТОРЫХ УСТАРЕВШИХ НАРОДНЫХ ГЕОГРАФИЧЕСКИХ ТЕРМИНАХ ЗАПАДА НОВГОРОДСКИХ ЗЕМЕЛЬ}

В статье по материалам новгородских писиовых книг рассмотрены особенности двух главных семантических групп топонимов запада Новгородских земель - локативных (указывающих на связь именуемого объекта с другим объектом) и квалитативных (морфология объекта). Аналитическая часть статьи предваряется краткой характеристикой топонимической изученности региона и анализом ключевых природных особенностей региона, влияюиих на номинацию поселений. $B$ статье обоснована геолого-географическая информативность названий поселений Новгородских земель. Автор предлагает рассмотрение отдельной группы топонимов смешанного типа - локативно-квалитативных, особенно характерных для ранних стадий становления топонимической картины региона (начальная фиксация больиинства названий малых населённых пунктов в официальных государственных документах). Предложены авторские версии происхождения таких основ в топонимах как: «лезье» (крыло излучины), «килом» (клин - для изолированного водой участка суци характерной клиновидной формы). Обоснована локативнал и квалитативная составляющая в названиях ряда исчезнувших и сохранившихся деревень территории бывшей Водской пятины. Высказана версия появления диалектных народных географических терминов на территории Новгородских земель.

Ключевые слова: локативные топонимы, квалитативные топонимы, географические термины, Новгородские земли, Водская пятина, Ингерманландия.

Для цитирования: Цинкобурова М. Г. О некоторых устаревших народных географических терминах запада Новгородских земель // Псковский регионологический журнал. 2021. T. 17. № 3. С. 116-127. DOI: https://doi.org/10.37490/S221979310014961-0

\author{
M. Tsinkoburova \\ Mining University, St. Petersburg, Russia \\ E-mail: maschek@mail.ru
}

\section{ABOUT SOME OUTDATED FOLK GEOGRAPHICAL TERMS OF THE WEST NOVGOROD LANDS}

In an article based on materials from Novgorod scribes, the features of two main semantic groups of toponyms in the west of Novgorod lands are considered - locative (indicating the connection of the named object with another object) and qualitative 
(morphology of the object). The analytical part of the article is preceded by abriefdescription of the toponymic knowledge of the region and an analysis of the key natural features of the region that affect the nomination of settlements. The article substantiates the geological and geographical information content of the names of the settlements of the Novgorod lands. The author proposes to consider a separate group of mixed toponyms - locativequalitative, especially characteristic of the early stages of the formation of the toponymic picture of the region (the initial fixation of most of the names of small settlements in official state documents). The author's versions of the origin of such bases in toponyms as: lez'e (wing of the bend), kilom (wedge - for a land area isolated by water with a characteristic wedge-shaped shape) are proposed. The locative and qualitative components in the names of a number of disappeared and survived villages in the territory of the former Vodskaya pyatina have been substantiated. A version of the appearance of dialectal folk geographic terms on the territory of the Novgorod lands is stated.

Keywords: toponyms, geographical terms, Novgorod lands, Vodskaya Pyatina, Ingria.

For citation: Tsinkoburova M. (2021), About some outdated folk geographical terms of the west of Novgorod lands, Pskov Journal of Regional Studies, vol. 17, no. 3, pp. 116-127. (In Russ.). DOI: https://doi.org/10.37490/S221979310014961-0

Введение. Географические, в первую очередь, оро- и гидрографические особенности местности являются главными факторами, влияющими на формирование географических названий. При этом, согласно закону относительной негативности географических названий, наибольшее влияние оказывали самые яркие, отличающие из ряда других, обьекты. Эта закономерность способствует решению сразу двух задач - формированию базы народных географических терминов, а также получению информации о географическом объекте «глазами очевидцев». Решение первой задачи представляет определённую трудность, т. к. в составе топонимов присутствуют как устаревшие народные географические термины, так и диалектные слова, в связи с чем в любом регионе есть обширные группы этимологически неясных топонимов (особенно среди субстратных топонимов). Расширение наших знаний по народной географической терминологии оказывается комплексной задачей не только географии, но и лингвистики и истории. Топонимы отражают как этнокультурную характеристику местности на момент их формирования, так и дальнейшую историю региона. Выяснение этимологии топонимов, как и путей их дальнейшей трансформации, является крайне важной частью историко-географических и лингвистических исследований.

Состояние топонимической изученности региона. Как верно указывал исследователь архаической новгородской топонимии В. Л. Васильев «B иелом древняя Новгородская земля подвергалась недостаточному, спорадическому, разрозненному топономастическому изучению...» [4, с. 7]. Первые топонимические исследования региона совпадают с зарождением этого направления и связаны с работами А. Х. Востокова [5] и Н. И. Надеждина [14]. Работы носили общетеоретический характер и были посвящены сопоставлению топонимов европейской части России друг с другом и с топонимами других европейских стран. В первую очередь при анализе топонимического материала акцент делался на гидронимах, как на более древних для регионов топонимах. Была проведена первоначальная лингвистическая систематизация описываемого топонимического материала и выдвинут тезис о финно-угорском 
происхождении многих топонимов (гидронимов) региона. Более подробно история топонимического изучения русского севера рассмотрена в работе А. К. Матвеева [11].

На протяжении $\mathrm{XX}$ в. и по настоящее время среди изданий, посвящённых топонимике изучаемого региона, доминировала краеведческая литература, часто содержащая ошибочную информацию. Помимо этого, были изданы работы общетеоретического характера, посвящённые интерпретации топонимического материала в этноязыковом и культурно-историческом аспекте $[1 ; 2 ; 10 ; 12 ; 26]$; в стенах Петербургского университета создаётся топонимическая база Ингерманландии, содержашая информацию о вариантах названий на русском и других языках. Как было давно отмечено [7; 18], топонимы являются ценнейшим материалом при историко-географических исследованиях, отражая, в частности, народную географическую терминологию времени формирования топонимов. Наиболее фундаментальной работой, обобщающей народные географические термины территории всего бывшего СССР, был знаменитый словарь народных географических терминов Э. М. Мурзаева [13], для Карелии и Приладожья работы И. И. Муллонен [12], а также диалектные и толковые словари разных лет. Несмотря на кажущееся разнообразие как общетеоретической, так и региональной топонимической литературы и в настоящее время многие вопросы этимологии, систематизации топонимов региона так и не выяснены полностью.

Особенности топонимического пространства Новгородских земель. Под Новгородскими землями обычно понимают как собственно новгородские, так и псковские земли, а также обширную территорию позднейшей новгородской колонизации на северо-востоке Европейской части России. После присоединения этих земель к Московскому государству стало принятым деление Новгородских земель на пять частей, пятин (возможно применявшееся и раннее). Запад новгородских земель соответствует территории Водской и Шелонской пятин (с точки зрения современного административного деления это - значительная часть Ленинградской области, Псковская область, западная половина Новгородской области).

Топонимическая картина края отличается большой пестротой. Среди топонимов региона есть как обширный пласт суб́стратных топонимов, так и трансформированных (часто неоднократно трансформированных) топонимов. Топонимия усложняется в северных районах региона, достигая максимального разнообразия на территории Ленинградской области. Топонимическое своеобразие этих земель было обусловлено историко-этническими особенностями местности, исходно район являлся территорией совместного проживания различных финно-угорских народов (в большинстве своём исчезнувших, а также ижор, карелов, вепсов, эстонцев, води) и славян. В 1478 г., после поражения во второй московско-новгородской войне земли Великого Новгорода присоединились к России. С этим моментом связана первая обширная фиксация в писцовых книгах многих малых ойконимов региона (писцовая книга Водской пятины, 1499-1500 год; Шелонской пятины, 1571, 1572 год). Так как писцы, составлявшие книги, были московские, и для них были чужды местные диалекты, рассматриваемые как древний новгородско-псковский диалект [8], они допускали ошибки при написании местных названий, что также способствовало дальнейшей трансформации топонимов. Несмотря на указанные погрешности, новгородские писцовые книги (как и шведские писцовые книги Ижорской земли) являются бесценным историческим материалом.

В Смутное время в связи с глубоким социально-экономическим кризисом в краю началось запустение: исчезновение деревень, сокращение численности населения. 
Шведская интервенция в восьмидесятые годы XVI в. усугубила сокращение численности населения и опустошение края. После того как северная часть новгородских земель перешла во владение Швеции (по итогам Столбовского мира, 1617 г.), превратившись в шведскую провинцию Ингерманландия, на опустевшие земли Ингерманландии шведские власти переселили финнов - эвремейсов из северо-западной части Карельского перешейка и савакотов из провинции Саво. Так начала формироваться новая популяция финнов - ингерманландцев, значительным образом повлиявших также на дальнейшее формирование топонимической картины региона. После возврата Ингерманладнии России (1703 г.) начался стремительный приток русского населения, формирование столицы Российской империи способ́ствовало появлению иностранцев. Следствием этих процессов явилась мода на русские названия, русификацию старых, немецкие топонимы. Последний кардинальный этап дальнейших топонимических преобразований региона пришёлся на советское и постсоветское время и был обусловлен идеологическими причинами.

Геолого-географические особенности Новгородских земель, влияющие на топонимию региона. Как многократно отмечалось в ходе топонимических исследований, природные особенности местности (в первую очередь, характер рельефа, гидросети, озёр, ландшафты, в меньшей степени - литолого-петрографическое своеобразие, растительный мир) оказывали наибольшее влияние на номинацию местоположений на ранних стадиях заселения. Несмотря на общий равнинный характер Новгородских земель (основная часть описываемой территории расположена в пределах Прибалтийской низменности), наблюдается чередование возвышенностей (Ижорская, Лужская, Судомская, Бежаницкая, Волховское плато), разделённых низменностями (Псковская, Приильменская, Приморская, Предглинтовая, Приладожская). Все вышеперечисленные формы макрорельефа осложнены террасированным (в районах низменностей, оконтуривающих крупные водоёмы) и гетерохронным холмисто-грядовым структурно-денудационным и экзарационно-аккумулятивным ледниковым рельефом.

Подобный мозаичный характер рельефа и ландшафтов способствовал формированию и развитию обширной базы народной географической терминологии, отразившейся в топонимии региона. В первую очередь это касается значительного пласта общерусских и общеславянских терминов (как утраченных, так и находящихся в активной лексике), прослеживающийся в зоне давнего и более молодого славянского расселения. К примеру, для положительных элементов рельефа это многочисленные топонимы с основами горка (только на территории Ленинградской области таких топонимов насчитываются десятки - Красная Горка, многочисленные Горки, Пятая Гора и т. д.); грива (Борисова Грива, Всеволожский район Ленинградской области; Грива - Хвойнинский район Новгородской области, 2 деревни в Вологодской области, 2 деревни в Калужской области и т. д.). Для описания такого характерного элемента речных долин, как место слияния двух рек, часто использовался термин $c y$ тока (Деревня на сутоке, на реще на Тосной, Никольский Ижорский погост Водской пятины [17, с. 431]; Сутоки - Себежский и Бежаницкий районы Псковской области; Мошенский, Боровичский, Окуловский районы Новгородской области; 2 деревни в Московской области и т. д.).

Указатели на особенности географических объектов можно встретить в различных семантических группах топонимов: в локативных (указывающих на связь име- 
нуемого объекта с другим объектом) и квалитативных (морфология объекта). Как было указано у А. А. Соколовой [21, с. 136] к понятию «морфология объекта) относится широкий спектр свойств: не только обще признаваемые размеры и форма, но и «цвет», состав отложений; ресурсные особенности; для водотоков - водный режим и степень зарастания». По нашему мнению, часто уместнее говорить о смешанных локативно-квалитативных топонимах, что хорошо видно на примере названий малых селений новгородских земель (как сохранившихся до настоящего времени, так и утраченных). Наглядным примером топонимов подобного смешанного типа является отмеченная в писцовой книге Водской пятины в Введенском Дудеровском погосте деревня Савелово на Дудеров Глинища [17, с. 332]. Деревня была утрачена ещё в XVII в., когда север пятины относился к Шведской Ингерманландии, и православное население мигрировало на русскую территорию. Центральные погосты Водской пятины (Веденский Дудеровский и Никольский Ижорский) характеризовались преимущественно русским населением, в отличие от западных погостов (Каргальского, Григорьевского Льешского, Ильинского Замоского, Никольского Толдожского в Чюде), в которых было много вожан и ижор. В результате большинство поселений, находившихся в Введенском Дудеровском и Никольском Ижорском погостах в шведское время, обезлюдели, деревни исчезли. Несмотря на это, можно довольно точно локализовать положение деревни Савелово на Дудеров Глинища. Под Дудеров подразумеваются Дудергофские высоты (ещё в XIX в. иногда фигурировавшие под названием Дудеровские), в такой ситуации на Дудеров можно рассматривать как локативную часть сложного составного топонима. Глинища - квалитативная часть, указывающая на свойства возвышенности. Несмотря на продолжающиеся и по сей день дискуссии о природе Дудергофских и Кирхгофских высот, есть многочисленные свидетельства о структуре, напоминающей глиняный диапир на вершине Кирхгофской горы, в ядре диапира обнажались глины лонтоваского горизонта нижнего кембрия [15]. Другие по генезису и составу глины, но крайне увеличенной по сравнению с остальной территорией мощности, наблюдаются на Дудергофских высотах, это валунные суглинки [9]. Таким образом, широкое распространение глин и глинистых отложений на возвышенностях действительно является отличительной чертой этого места. Писец, желая точно описать расположению деревни, добавил к её названию уточняющие характеристики. Однако в последующих работах (как на картах, так и в более поздних писцовых и дозорных книгах) часто фигурировали уже такие, взятые из первых книг комплексные составные названия. Подобные локативно-квалитативные топонимы были характерны для относительно ранней стадии формирования топонимии региона, в дальнейшем они упрощались путём трансформации усечением. Приведённый пример в очередной раз показывает, что при номинации местоположений отмечали важнейшие детали местности. В данной работе мы остановимся на устаревших географических терминах, имевших исключительно локальное распространение.

Анализ устаревших географических терминов в топонимах региона, отражающих природные особенности. Устаревиие термины, указывающие на орографические особенности местности. В писцовой книге Водской пятины в Егорьевском Вздылицком погосте упомянуто село Bздыллицы [16, с. 861], в настоящее время это Дылицы (Гатчинский район, Ленинградская область). Основу данного топонима составляет слово воздыlм, въздым - подъём [24, с. 282]. Появление подобного термина для обозначения местности, вероятно, было обусловлено грядовым рельефом, 
получившим широкое развитие в пределах всей Ижорской возвышенности и, в частности, наличием гряды в окрестностях указанной деревни.

Устаревиие термины, указываюиие на гидрографические особенности местности. Хорошо развитые речная и озёрная сети, способствующие мозаичному характеру ландшафтов и порой резко выраженному обособлению местоположений, способствовали формированию серии терминов. Один из таких терминов был сформирован от старорусского слова лезъ - острие клинка [23, с. 164], это слово встречается в названиях двух деревень в Никольском Ижорском погосте Водской пятины: деревня Лезыъ на рече на Неве [16, с. 366], деревня Колено на речке на Лезыь [16, c. 366]. На карте Ижорского погоста [27] на левом берегу Невы, у излучины ниже устья Славянки отмечены деревня. Лезье (на северо-западном крыле излучины) и Колено (на юго-восточном крыле излучины) (рис. 1).

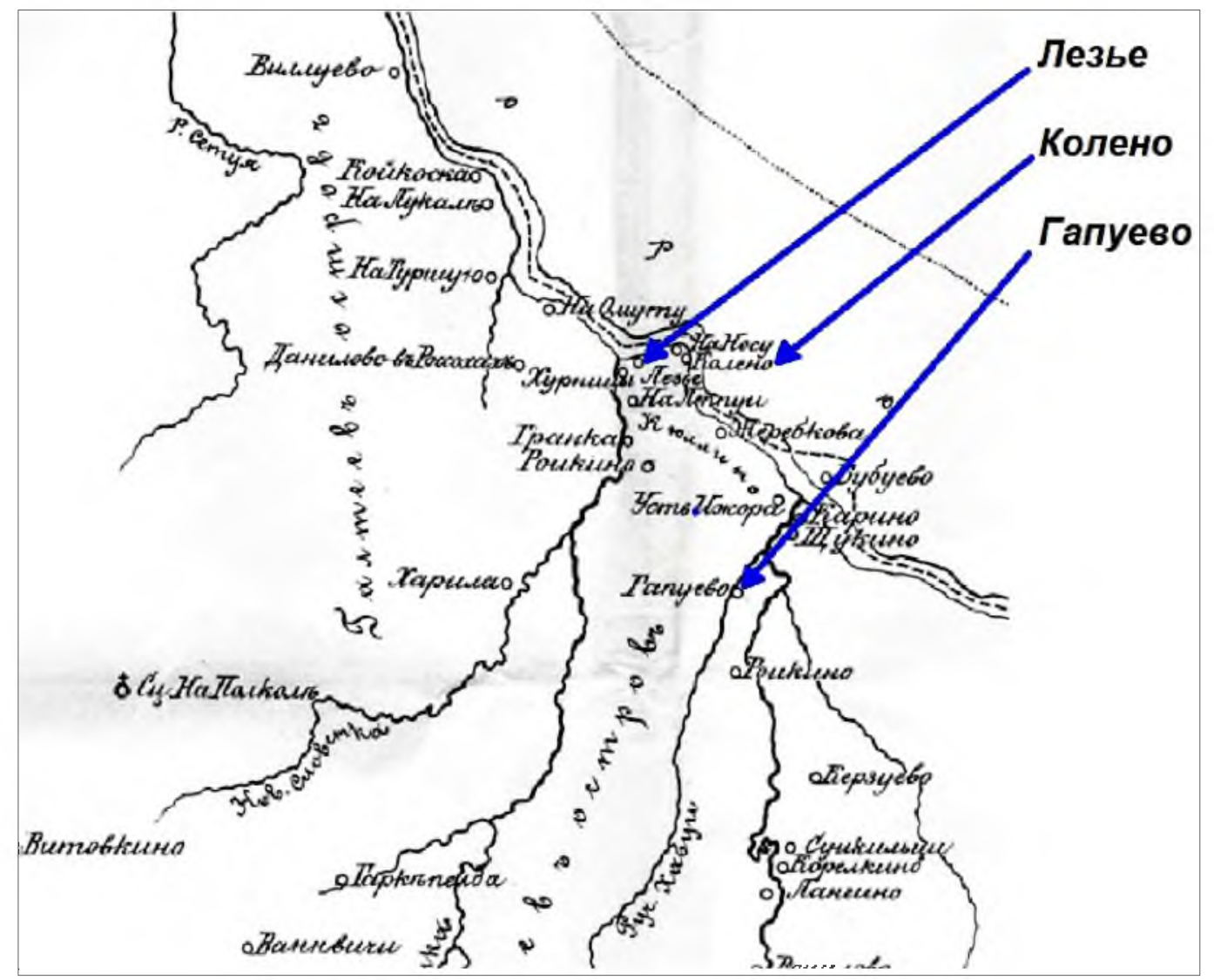

Рис. 1. Фрагмент карты Ижорского погоста [27]

Fig. 1. Fragment of the map of the Izhora pogost [27]

Приуроченность обеих деревень к характерному элементу речной долины, крылу излучины, позволяет предположить ещё одно значение данного слова. О сохранение слова в диалектной лексике подтверждает и словарь В. И. Даля (лезье, лезо острие ножа [6, с. 250]) и данные диалектных словарей (лезво - лезвие у косы, зафиксировано в Чудовском районе Новгородской области [19, с. 108]), аналогичное 
значение данное слово имеет в украинском, белорусском языке. Отсутствие подобной основы в топонимах не только других регионов России, но и в других топонимах новгородских земель свидетельствует о локальном распространение данного народного географического термина.

Как было раннее показано нами [25, с. 225], с небольшим участком суши, обособленным от остальной территории водоёмами, предположительно был связан устаревший народный географический термин килом (клин?). Отражение этого термина можно увидеть в таких названиях как деревня на Киломе в Гапуев на Ижоре (Никольский Ижорский погост) [16, с. 349]. Эта деревня, как и многие деревни Никольского Ижорского погоста, утрачена в XVII в. На карте Ижорского погоста отмечена деревня Гапуево, действительно расположенная на клиновидном мысу между рекой Ижсрой и ручьём Хабуи (Попоповым ручьём?) (см. рис. 1). Также подобный термин лёг в основу названия деревни в Никольском Будковском погосте Водской пятины - Килож над озером Килом [16, с. 325] (современное название деревни, полученное в процессе сложной трансформации - Келло, Лужский район, Ленинградская область). В данной ситуации наблюдался случай менее привычной топонимической метонимии - перехода названия деревни на название озера (название озера также не сохранилось, современное название озера Меревское). Полная утрата исходных названий озера и деревни может служить косвенным доказательством ранней утраты данного народного географического термина. Как и в предыдущем случае данный термин был достаточно мало употребителен.

Устаревиие термины в топонимах с неясной локативной или квалитативной семантикой. В ситуации трансформированных топонимов определение исходной формы, как и этимологии названия, часто представляет достаточно большую сложность. Одним из довольно частых примеров трансформации является трансформация путём усечения. Примером таких трансформированных топонимов является деревня Пехенеи (Лужский район, Ленинградская область); первое упоминание деревни в писцовых книгах было как Максимов Пихенеи [16, с. 331]. Автору посчастливилось найти упоминание в новгородских берестяных грамотах возможного владельца этих земель - Максима, владевшего землями ещё во второй половине XIV в. В обнаруженной грамоте речь шла о продаже земель, принадлежащих некоему Максиму «Поклонъ Синофонта ко брату моему Офоносу. Буди тоби сведомо, Купиле ксомъ перво Максима Ђщерски уездъ і Замолмовсови і свою сироти в Симовли, а на Хвоіни. А Максиме, Іване Широки ту же быле ... » [3, с. 63]. Описанные в грамоте земли Ящерский уезд и Замолмовсови - располагались вокруг реки Ящеры и за Молосовскими озёрами соответственно (рис. 2).

Деревня Пехенеи расположена на правом берегу р. Ящера, у вершины излучины. Пихенеи в составном топониме Максимов Пихенеи был локативной или квалитативной характеристикой, указывающей на особенности местоположения. В словарях древнерусского языка данное слово не выявлено, особенности морфологии долины реки Ящера в этой местности (река, характеризующуюся чередованием песчаных отмелей и омутов; в берегах реки обнажаются красноцветные песчаники аракюлаской свиты живетского яруса среднего девона, подверженные суффозии) позволяют предположить достаточно широкий комплекс примет: броды, пещеры, вышеупомянутая излучина. В диалектном словаре Карелии пихняк - молодой ельник [20, с. 525], что подходит ландшафтам окрестностей деревни. Однако возможна и альтернативная версия - слово, определяющее тип поселения. 


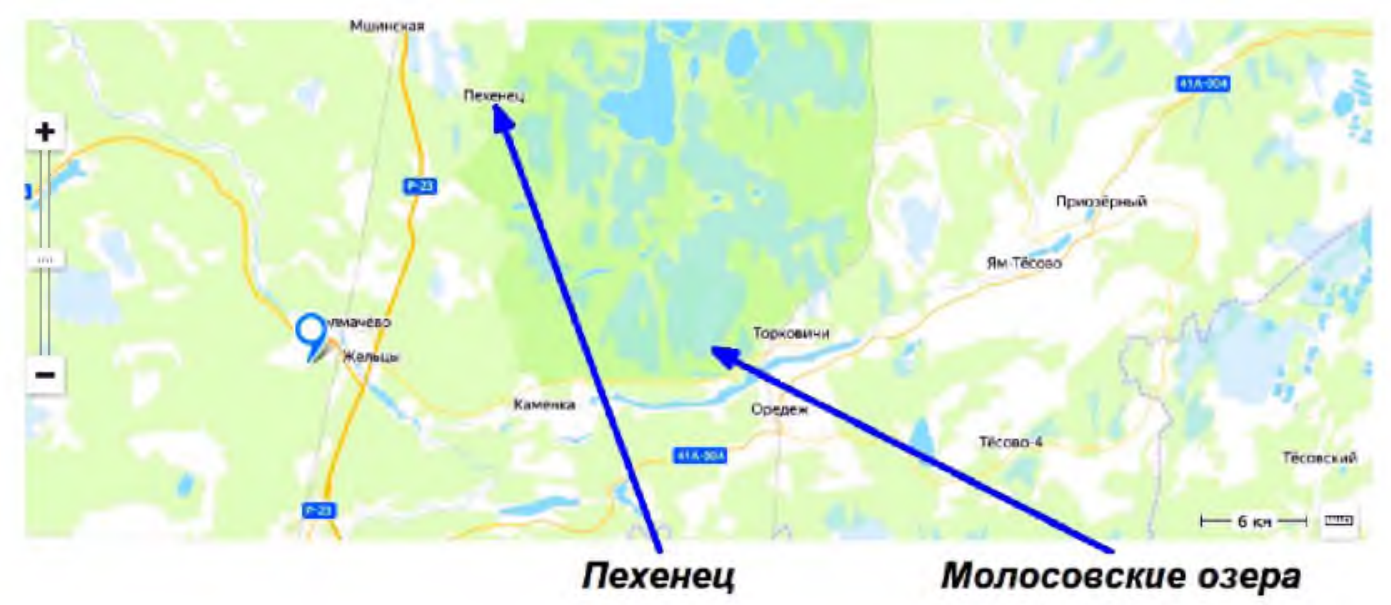

Рис. 2. Фрагмент карты Лужского района ${ }^{1}$

Fig. 2. Fragment of the map of the Luga region

Вероятно, с особенностями морфологии долины реки Славянка было связано появление таких названий, как Деревня на Перилах на Словенке же [16, с. 400], Деревня Паперилах [16, с. 350] (Никольский Ижорский погост). Данный термин перила в топониме имел явно локативное значение, конкретизируя расположение деревни в пределах долины реки. К сожалению, точная локализация этих деревень не возможна, аналогичные названия в других погостах новгородских земель или в других регионах России не обнаружены, поэтому говорить о значение данного народного географического термина не предоставляется возможным. Отсутствие данного термина (как и предыдущего) в словарях древнерусского языка, древненовгородского диалекта обусловлено, вероятно, в первую очередь тем, что данные словари составлялись в основном за счёт чтения и интерпретации берестяных грамот и памятников древнерусской письменности, а этот материал касался диалектов городских и около городских территорий. Указанные названия позволяют увидеть еще одну особенность новгородских писцовых книг - ошибки писца, отчётливо проявляющуюся, например, при описании Никольского Ижорского погоста. Так название на Перилах появляется на одной и той же странице трижды, первый раз - несколько в другой транскрипции, деревня на Перим на Словенской; второй раз с пояснением - на Словенке же; третий раз - без пояснения, Деревня на Перилах же. Не следует считать это как названия трёх различных деревень, а скорее как повтор писцом названия одной и той же деревни в ситуации описания новых дворов, с которых взимались подати. Таких примеров при описании указанного погоста насчитывается довольно большое количество. Аналогичной ошибкой писца можно считать название деревни Деревня Паперилах (вероятно описка вместо на Перилах).

Не всегда локативной составляющей топонимов становятся географические термины. Это отчётливо видно на примере серии деревень, упомянутых при описание Ильинского Тигодского погоста: деревня Середка Сусье на реце на Тигоде [16, с. 359]; деревня Конеи Сусье на Тигоде [16, с. 359], современное название - Cустье-Конеи (Тосненский район, Ленингрдская область); деревня Сусье на Тигоде [16, с. 359].

\footnotetext{
[Электронный ресурс]:URL: https://maps-online.ru/leningradskaya-oblast/luzhskii-raion/
} 


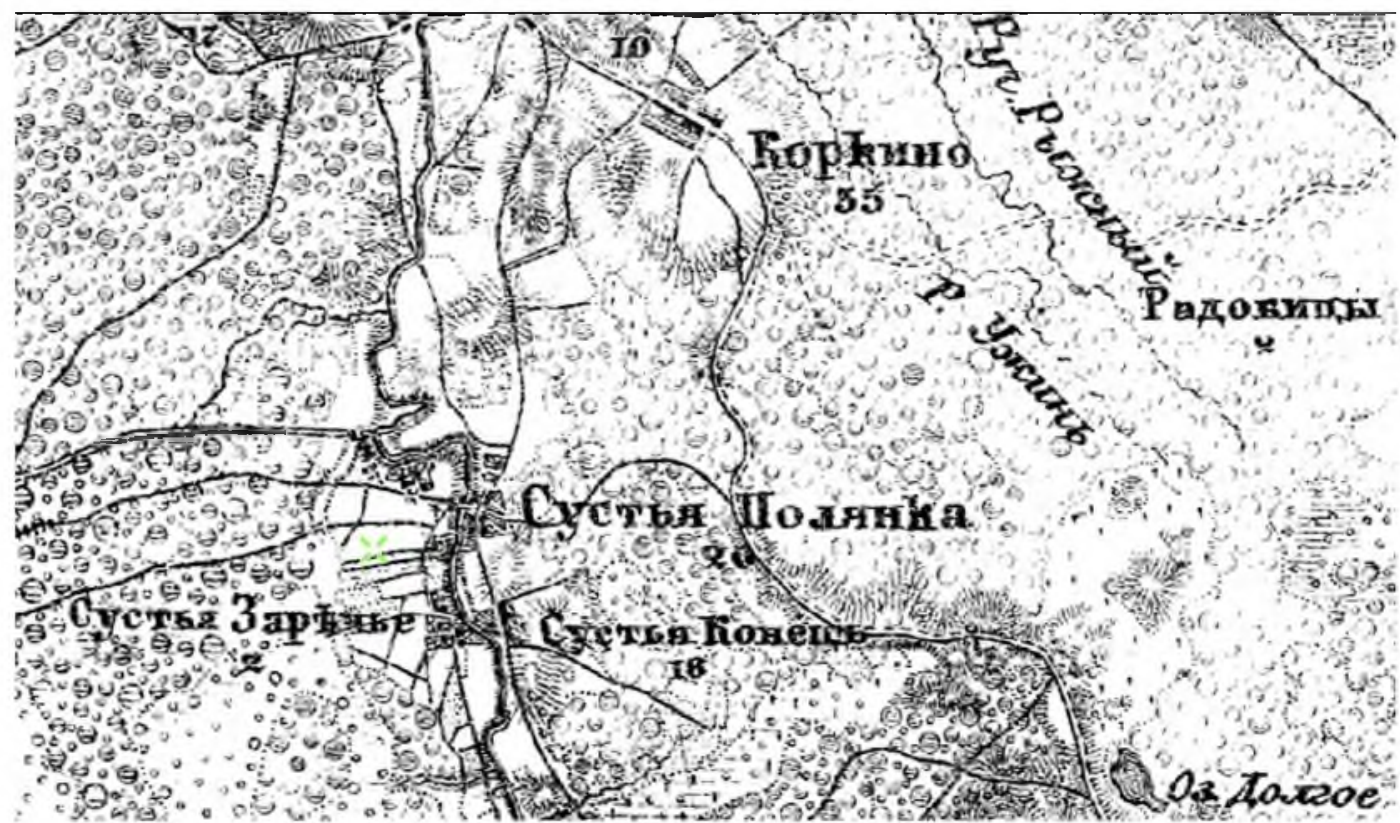

Pис. 3. Фрагмент карты Санкт-Петербургской губернии [28]

Fig. 3. Fragment of the map of St. Petersburg province [28]

B XIX в. все три деревни существовали на берегах реки Tигоды: Середка Сусье на реце на Тигоде именовалась Сустья Заречье, а Сусье на Тигоде - Сустья Полянка (рис. 3). Локативная часть составных топонимов была образована от старорусского слова сусь - друг против друга [22, с. 628].

Выводы. Согласно проведённому анализу достаточно большое количество топонимов, локативная или квалитативная часть которых может быть соотнесена с географическими терминами, локализованы в центральных и южных погостах Водской пятины. Данные погосты характеризовались доминированием православного славянского населения (в отличие от западных погостов «в Чуди»). Вероятно, в русских погостах начинали проявляться какие-то индивидуальные диалектные черты. Миграция православного славянского населения во время шведской Ингерманландии привела к нарушению только начавшей формироваться диалектной общности и утрате ряда диалектных слов.

\section{Литература}

1. Агеева P. А. Гидронимия русского северо-запада как источник историко-культурной информации М.: Едиториал УРСС. 2004. $256 \mathrm{c}$.

2. Амбросиани П. Параллельные названия в прибалтийско-финской и русской ойконимии Ингерманландии // Вопросы ономастики. 2008. № 6. С. 83-92.

3. Арииховский А. В., Борковский В. И. Новгородские грамоты на бересте из раскопок 1955 года. T. IV. M.: AH CCCP, $1958,152 \mathrm{c}$.

4. Васильев В. Л. Архаическая топонимия Новгородской земли (Древнеславянские деантропонимные образования). Великий Новгород, 2005. 468 с

5. Востоков A. X. Задача любителям этимологии // Санкт-Петербургский вестник. СПб., 1812. Т. 1 № 2. C. 204-215. 
Псковский регионологический журнал Том 17. № $3 / 2021$

6. Даль В. И. Толковый словарь живого великорусского языка. Том второй. И - О. СПб., М., тип. М. О. Вольфа. 1881.814 с.

7. Жекулин В. С. Историческая география ландшафтов. Новгород, 1972. 228 с

8. Зализняк A. А. Древненовгородский диалект. М.: Языки славянской культуры. 2004. 872 с

9. Малаховский Д. Б., Саммет Э. Ю. Ледниковые отторженщы и гляциодислокации северо-запада Русской равнины // Материалы гляпцилогических исследований. Хроника, обсуждения. 1982. № 44. C. $121-128$.

10. Манаков А. Г. Этногенез славян по данным топонимии (историко-географическое исследование). Псков: Псковский государственный университет, 2007. 254 с

11. матвеев А. К. Субстратная топонимия Русского Севера. Часть I. Екатеринбург: Изд-во Урал. ун-та, $2001.346 \mathrm{c}$

12. Муллонен И. И. Топонимия Заонежья: Словарь с историко-культурными комментариями. Петрозаводск, 2008. 242 с.

13. Мурзаев Э. М. Словарь народных географических терминов. М.: Мысль. 1984. 653 с.

14. Надеждин Н. Н. Опыт исторической географии русского мира // Библиотека для чтения. Т. 22. Отд. ІІІ. Ч. 2. СПб., 1837. С. 27-79.

15. Никитин М. Ю. О генетической приуроченности месторождений голоценовых пресноводных карбонатов к особенностям структурного плана Ижорского плато // Известия Российского государственного педагогического университета имени А. И. Герценаю 2011. № 138. С. 100-110.

16. Новгородские писцовые книги изданные археографической комиссией. Переписная оброчная книга Вотской пятины 1500 года. Первая половинаю СПб.: типография В. Безобразова и комп. Том третий, $1868.488 \mathrm{c}$.

17. Переписная Окладная книга по Новгороду Водской пятины 7008 года // Временник Московского общества истории и древностей российских. М.: Университетская типография. Книга 11. 1851. C. $1-464$.

18. Семёнов-Тян-Шанский В. П. Как отражается географический пейзаж в народных названиях населенных мест. Землеведение. Т. 26, 1924. С. 133-158.

19. Словарь русских говоров Карелии и сопредельных областей / Гл. ред. А. С. Герд, ред. вып. О. А. Черепанова. СПб.: Изд-во Санкт-Петербургского университета. Вып. 3. (Кот - Немовый). 1996. 416 с

20. Словарь русских говоров Карелии и сопредельных областей / Гл. ред. А. С. Герд, ред. вып. О. А. Черепанова. СПб.: Изд-во Санкт-Петербургского университета. Вып. 4. (Необрятный - Подузорник). $1999.688 \mathrm{c}$.

21. Соколова A. А. Географическое пространство в народной терминологии и топонимии Русского Устья // Вестник СВФУ. 2017. № 6 (62). С. 130-141.

22. Срезневский И. И. Материалы для словаря древнерусского языка по письменным памятникам. СПб.: типография Императорской Академии наук. Том 3. 1912. $996 \mathrm{c}$.

23. Срезневский И. И. Материалы для словаря древнерусского языка по письменным памятникам. СПб.: типография Императорской Академии наук. Том 2. 1902. 919 с.

24. Срезневский И. И. Материалы для словаря древнерусского языка по письменным памятникам. СПб.: типография Императорской Академии наук. Том 1. 1893. $771 \mathrm{c}$.

25. Ццинкобурова М. Г. Историко-географический аспект топонимического анализа пведских и русских писцовых книг для территории бывшей Водской пятињы // Геология, геоэкология, эволюционная география. XVIII. СПб.: Изд-во РГПУ им. А. И. Герцена. 2019. С. 222-227.

26. Kepsu Saulo. Inkerin pogostat. Vanha nimistö ja asutus Helsinki: Kotimaisten kielten keskus. 2010. 938 p.

27. Карты Водской пятины и её погостов в 1500 г. Сост. Архимандрит Сергий. СПб.: Картограф. заведение А. Ильина. 1905.

28. Нуберт. Топографическая карта Санкт-Петербургской губернии: 5-и вёрстка, 1834

\section{References}

1. Ageeva R. A. (2004), Hydronymy of the Russian North-West as a source of cultural and historical information, Moscow, 256 p. (In Russ.).

2. Ambrosiani P. (2008), Parallel Names in Balto-Fennic and Russian Oikonymy of Ingria, Voprosy onomastiki, no. 6, pp. 83-92. (In Russ.).

3. Artsikhovsky A. V., Borkowski V. I. (1958), Novgorod charters to bark. From excavations 1955, vol. IV, Moscow, 152 p. (In Russ.). 
4. Vasiliev V. L. (2005), Archaic toponymy of the Novgorod land (Old Slavic deanthroponymic formations), issue 4, Veliky Novgorod, 468 p. (In Russ.).

5. Vostokov A. Kh. (1812), An example to the amateurs of etymology, vol. 1, no. 2, St. Petersburg, pp. 204-215 (In Russ.).

6. Dal V. I. (1881), The Explanatory Dictionary of the Living Great Russian Language, vol. 2, St. Petersburg, 814 p. (In Russ.).

7. Zhekulin V. S. (1972), Historical geography of landscapes, Novgorod, 228 p. (In Russ.).

8. Zaliznyak A. A. (2004), Ancient Novgorod Dialect, Moscow, 872 p. (In Russ.).

9. Malakhovskii D. B., Sammet E. Yu. (1982), Glacial outcrops and glaciodislocations of the North-West of the Russian plain, Materialy glyatsiologicheskikh issledovanii, 44, pp. 121-128. (In Russ.)

10. Manakov A. G. Ethnogenesis of the Slavs according to toponymy data historical and geographical research) (2007), Pskov, Pskov State University, 254 p. (In Russ.).

11. Matveyev A. K. (2001), Substrate Toponymy of the Russian North, Part 1, Ekaterinburg, 346 p. (In Russ.).

12. Mullonen I. I. (2008), Review of Topomymy of the Trans-Onega Region: a Dictionary with Historic and Cultural Commentaries, Petrozavodsk, 242 p. (In Russ.).

13. Murzaev E. M. (1984), The Dictionary of Folk Geographical Terms, Moscow, 653 p. (In Russ.)

14. Nadezhdin N. I. (1837), Experience of historical geography of the Russian world, Biblioteka dly chtenia, vol. 22, ser. III, ch. 2, St. Petersburg, pp. 27-79. (In Russ.).

15. Nikitin M. Yu. (2011), On the genetic association of Holocene freshwater carbonate deposits with the structural features of the Izhora plateau, Izvestiya Rossiyskogo gosudarstvennogo pedagogicheskogo universiteta imeni A. I. Herzen, no. 138, pp. 100-110. (In Russ.).

16. Novgorod scribal books published by the Archeographic Commission. Census tax book of the Votskaya Pyatina of 1500. The first half (1868), St. Petersburg, vol. 3, 488 p. (In Russ.)

17. The census salary book for Novgorod of the Vodskaya Pyatina of 7008 (1851), Annals of the Moscow society of Russian history and antiquities, book 11, Moscow, pp. 1-464. (In Russ.).

18. Semyonov-Tyan-Shanskij V. P. (1924), How the geographical landscape is reflected in the folk names of populated places, Zemlevedenie, vol. 26, pp. 133-158. (In Russ.)

19. Dictionary of Russian dialects of Karelia and adjacent regions (1996), St. Petersburg, issue 3 (Cat Nemovy), 416 p. (In Russ.).

20. Dictionary of Russian dialects of Karelia and adjacent regions (1999) St. Petersburg, issue 4 (Neobryatny — Poduzornik), 688 p. (In Russ.)

21. Sokolova A. A. (2017), Geographical space in folk terminology and toponymy of the Ruskoje Ust'e, Vestnik SIFU, no. 6 (62), pp. 130-141. (In Russ.).

22. Sreznevsky I. I. (1912), Materials for the dictionary of the Old Russian language in the Written Records, vol. 3, St. Petersburg, 996 p. (In Russ.).

23. Sreznevsky I. I. (1902), Materials for the dictionary of the Old Russian language in the Written Records, vol. 2, St. Petersburg, 919 p. (In Russ.).

24. Sreznevsky I. I. (1893), Materials for the dictionary of the Old Russian language in the Written Records. St. Petersburg, printing house of the Imperial Academy of Sciences, vol. 1, 771 p. (In Russ.).

25. Tsinkoburova M. G. (2019), Historical and geographical aspect of the toponymic analysis of Swedish and Russian scribal books for the territory of the former Vodskaya Pyatina, Geologiya, geoe 'kologiva, e'volyucionnaya geografiya, pp. 222-227. (In Russ.).

26. Kepsu Saulo (2010), Inkerin pogostat. Vanha nimistö ja asutus, Helsinki, 938 p. (In Finn.).

27. Maps of the Vodskaya Pyatina and its churchyards in 1500 (1905), Compiled by Archimandrite Sergius, St. Petersburg.

28. Topographical Map of St. Petersburg Province (1834), Compiled at the Scale of 1:210,000 on the Basis of Major-General Fedor Schubert, St. Petersburg.

\section{Сведения об авторе}

Цинкобурова Мария Георгиевна - кандидат геолого-минералогических наук, доцент кафедры исторической и динамической геологии Горного университета, Сангт-Петербург, Россия.

E-mail: maschek@mail.ru

ORCID: 0000-0001-8832-9182

Scopus Author ID: 56416375100 


\section{About the author}

Dr Maria Tsinkoburova, Associate Professor of the Department of Historical and Dynamic Geology of the Mining University, St. Petersburg, Russia.

E-mail: maschek@mail.ru

ORCID: 0000-0001-8832-9182

Scopus Author ID: 56416375100

Поступила в редакцию 09.05.2021 2.

Поступила после доработки 20.06.2021 2.

Статья принята к публикации 14.10.2021 2.

Received 09.05.2021

Received in revised form 20.06.2021

Accepted 14.10.2021 